\title{
Perception of Social Media Use and Effect on Academic Life: Students' Perspective
}

\author{
Martin Mabeifam UJAKPA ${ }^{1}$, Jude Odiakaosa OSAKWE ${ }^{2}$, Gloria Ejehiohen IYAWA ${ }^{2}$, and Valerianus \\ HASHIYANA $^{3}$, Lucy KIANA ${ }^{4}$ and Aussie Nkrumah MUTALYA ${ }^{1}$
}

\begin{abstract}
Social media has impacted several areas of life and among them is communication and education. Through social media, people reach out to loved ones in nearby and faraway places. As a communication tool, students and lecturers could leverage on it to interact among themselves. Such communications could affect student academic life and performance effect, hence, social media having an effect on student academic life. To investigate the perceived effect of social media on student academic life, this study applied the quantitative research design approach to collect data from 96 students in three universities in Namibia. The study found that social media can be used for academic purposes and thus far used to support student academic life to a very high extent. As a resu

It of this, students rated social media as a good platform. This is a wakeup call to stakeholders of education to understand that mobile devices and social media have come to stay and are widely used by students even for academic purposes.
\end{abstract}

Keywords - Social media, education, learning, university, effect, use, students, academic life, performance, and perception, smartphones, and Internet access.

\section{INTRODUCTION}

Social media has changed and greatly impacted the world [1] [2]. Since the creation of 'six degrees' (the maiden identifiable social media platform in its current form in 1997) to Myspace (the maiden social media platform to reach a million monthly active users as at 2004), social media has grown exponentially [3] [2] [4] [5]. Currently, Facebook as the current largest social media platform has over 2.4 billion users [1] [2].

Other social media platforms (including YouTube and WhatsApp) have more than one billion users each. Of the 7.7

Manuscript received June 30, 2019. M. M. Ujakpa is with Durban University of Technology, South Africa as a PhD Candidate and the International University of Management, Namibia as a Senior Lecturer and Faculty Dean. Previously he was with Ghana Technology University College, Accra Institute of Technology and Valley View University. Dr. Jude Odiakaosa OSAKWE and Dr. Gloria Ejehiohen IYAWA are Senior Lecturers at the Namibia University of Science and Technology, Namibia. Dr. Valerianus HASHIYANA is the Head of Department at the School of Computing in University of Namibia. Ms. Lucy KIANA and Aussie N. MUTALYA serve as acting Librarian and Lecturer respectively at the International University of Management, Namibia. billion people in the world, at least 3.5 billion are online; indicating that one-in-three people in the world, and more than two-thirds of all, are internet users [2].

The increase in internet use has impacted on social media penetration rate throughout the world. Though social media penetration rate for Africa for 2019 (30.2\%) is less than the world penetration rate for $2019(51.1 \%)$ for the eligible population (13 years and above); the was still an increase in penetration rate for Africa compared to the previous year (18.6\%) [6]. Social media influences a wide range of areas in our society. Among these include access to information/news, politics, personal life, social life, healthcare [3] [2] [7] and education [8] [9] [10] [11] [12] [13] [14]. The increase in penetration rate throughout the world and Africa could mean an increased impact on a wide range of areas in the world including education.

According to [15] social media has been accepted by higher institutions as a platform where students and instructors connect with each other. Social media enhances the interaction between instructors and students as well as interaction amongst students [16] [17] [18]. Research on the impact of social media on education shows that students at the University of Minnesota discovered the educational benefits of social networking sites (such as Myspace and Facebook) [8][9][10][15].

Notwithstanding the impact of social media on education as enumerated above, there are challenges on the use of social media for educational purposes [10] [19]. Previous studies that concluded with similar findings include that of [19] and [20]. In a UK study conducted by [19], which investigated the challenges of social media use in a medical faculty, it was found that instructors had concerns for student professionalism, distraction and student-teacher relationship changes when using social media to deliver instructions. [20] Found that Italian university instructors' use of social media to deliver instructions is limited and restricted, and that instructors have very little interest in integrating social media into their instructional practices. Reasons accounting for this include cultural resistance, pedagogical issues, privacy concerns and institutional constraints.

As indicated by [10], some critical reviewers suggest that social media is un-conducive for educational purposes as it contains an explicit bias towards cordiality, sameness and lacks the critical components of disagreement and discourse.

Based on only one quantitative evaluation by [21] on mobile phone use in schools that found a very low-cost but effective policy to improve student performance, some policy 
makers worldwide have suggested and even passed legislation to ban mobile phone use in schools [22]. The ban on mobile phone use in schools means less access to social media and that is if other available computing devices (fixed or mobile) in the schools have access to internet. Frequent use of social media on mobile phones may lead to addiction to mobile phone which could also lead to nomophobia (fear of being detached from mobile phone connectivity). The concept of nomophobia may additionally encourage policy makers to ban the use of mobile phones in schools and, hence further restricting access to social media. Based on the impact of social media and mobile phones in education, the fact that the real and virtual world are co-existing and is a reality and also that the force of technological advancement cannot be ignored, [23] disagrees with a ban on use of mobile phones in schools. Instead, they suggest that limit to use be implemented. The challenges discussed above indicate a barrier to the adoption of social media to take advantage of its potential benefits as discussed above. [10] Quantifies this barrier as large as the potential benefits that social media offer to education.

Based on the challenges of social media and barriers to its adoption for educational purposes, as discussed above, further studies are required to establish the perception of the effect of social media on student academic life. This study therefore investigated the perception of the effect of social media on student academic life. The rest of this paper is structured as follows: Literature review is presented in Section 2. Methodology is presented in Section 3. The findings of the study are presented and discussed in Section 4 and 5 respectively. The paper concludes with recommendations in Section 6

\section{LITERATURE REVIEW}

Social media is a platform or system where persons or businesses can construct a public or semi-public profile of themselves within a bounded system, articulate a list of other users with who they share a connection, view and traverse their list of connections and those made by others within the bounded system, personal information and story sharing, para-social relationships and for business and professional purposes in the case of a few like [24] [25] as cited by [26].

Social media include Sixdegrees, Friendster, Myspace, Twitter, Facebook, YouTube, WhatsApp, WeChat, Viber, and Instagram among others [24]. Sixdegrees first appeared in the public domain in in 1997. Built on the concept of six degrees of separation that holds that a human being can be connected to another by approximately a chain of six levels. Based on the six degrees concept, friends were able to join the media by invites from their friends who were already on six degrees. Due to the fact that it couldn't provide a lot of activities for its users, low user interest of meeting strangers online and technological inability to allow seamlessly information sharing with ease, it failed to gain popularity and eventually closed in 2000 [26]. Inferring from practical usage of LinkedIn [24] and based on its mission statement ("connect the world's professionals to make them more productive and successful"), it is obvious that [24] is a social media that focuses on business and professional relationships [24] [26]. Apart from the rumours that Friendster social media was preparing to charge fees for its services,
Myspace added new features to its platform that enabled users to build their front page and profile, advertising, forum for interaction between bands and their fans, and user-demands compliance (such as requests for personalizing pages including background designs, and uploading information links), compelling users of Friendster social media to move onto Myspace. It reached its popularity peak when News Corp purchased it in 2005 and thereafter lost the popularity.

As an initiative between Mark Zuckerberg and his friends (Dustin Moskovitz, Chris Hughes, and Eduardo Saverin) at Harvard University, Facebook social media was developed solely for Harvard university students but gradually infiltrated into other universities in and around Boston [27]. Since announcing a membership of 500 million members in 2010 [28], Facebook users have grown tremendously and currently has 2271 active users per month [6]. Invented in 2006 by Jack Dorsey, Evan Williams, and Biz Stone as a faster means of staying in touch with people [29], Twitter has the feature of 280 limit characters (more than that of the usual SMS - 160 characters) that allows messages to be shared with connected people. Though initially used more by journalist to reach their readers at a faster pace, celebrities popularized it as they tweeted events of their daily lives on it [26].

Founded by Brian Acton and Jan Koum (2009) to allow statuses next to individual names of its user, WhatsApp application was developed. The application allows the exchange of text, image, video and audio messages and calls for 'free'. With increased active users, over 1500 per month in 2019, WhatsApp is the third largest social media network: after Facebook and YouTube [6]. Established by Chad Hurley, Steve Chen, and Jawed Karim in 2005, YouTube allows the upload \& download of videos and comments on the videos. With increased active users, over 1900 per month in 2019, YouTube is the second largest social media network: after Facebook [6].

Theoretically, [30] research on the uses and gratifications theory as cited by [31] explains the benefits obtained through mass media experience. The theory focuses on what people do with media rather than what media do with people. The people choose the media that suits their needs and actively use it: thus using it to fulfil specific gratification [31]. This implies that students could be using social media to fulfil some of their gratification and this could include their academic life needs. [32] confirm this as they indicate that seven different forms of gratification are derived from using social media and among them is information seeking and freedom of expression. Information being sorted for or to be discussed freely include academic information which could impact on academic performance if used appropriately. On behavioural intention to use technology, [33] concluded that perceived usefulness, perceived ease of use, perceived performance and perceived benefit of technology, influence the behaviour intention to use the technology: hence, as long as social media is perceived easy to use, useful performing and beneficial, students will increasingly use it. The increasing use could affect student academic life positively or negatively and hence the reason for this study to establish the impact of social media on student academic life. 


\section{Methodology}

The study employed a quantitative design approach. The study covered three universities in Namibia (University of Namibia, Namibia University of Science and Technology and the International University of Management). Questionnaire were used to collect data from 96 students in the three universities. The sample of 96 was chosen for convenience sampling as determining the proportions of students using social media within the universities populations was going to take longer that this research timeframe. Out of the 96 students, 55 students were chosen from the University of Namibia (UNAM), 20 from the International University of Management (IUM) and 21 from the Namibia University of Science and Technology (NUST). The basis for the sample size of each university was a result of its student population percentage as in Table 1.0.

TABLE I: POPULATION, \% OF POPULATION AND STRATIFICATION OF SAMPLE

\begin{tabular}{|c|c|c|c|}
\hline University & $\begin{array}{c}\text { Student } \\
\text { Population }\end{array}$ & $\begin{array}{c}\text { \% of } \\
\text { Population }\end{array}$ & $\begin{array}{c}\text { \% in } \\
\text { numbers }\end{array}$ \\
\hline $\begin{array}{c}\text { International } \\
\text { University } \\
\text { of } \\
\text { Management }\end{array}$ & 10000 & 20.8 & 20 \\
\hline $\begin{array}{c}\text { University } \\
\text { of Namibia }\end{array}$ & 28000 & 57.3 & 55 \\
\hline $\begin{array}{c}\text { Namibia } \\
\text { University } \\
\text { of Science } \\
\text { and }\end{array}$ & 11000 & 21.8 & 21 \\
Technology & 49000 & 100.0 & 96 \\
\hline Total & & & \\
\hline
\end{tabular}

The students chosen for the study were aged 18 and above. To ensure validity and reliability of the questionnaire, five experts reviewed it and made inputs into the initial questionnaire and after modifications; it was submitted to the Research and Ethics Committee of the International University of Management, Namibia for perusal and approval. Upon further modifications and approval by the ethics committee, a pilot study was administered three month(s) before the actual study commenced. After additional modification to the questionnaire, the final questionnaire was developed and the questionnaire placed online and the link distributed through email addresses (by blind copy) and student social media platform for them to visit the link and respond to the questionnaire. The first part of the questionnaire notified the students of informed consent and that they could choose to stop responding to the online questionnaire or and not submit their online response at all by ignoring the submit button and closing the survey. It was made clear that, opting out of the survey along the way had no consequences.

\section{ANALYSIS}

When asked whether they possess mobile devices or computers and whether their mobile devices (including phones) are smart or not, $100 \%$ of students (as in Figure 1.0) indicated that they possess mobile devices and that their mobile devices are smart. This indicated that the students had the necessary means by which to get access and participate in the social media activities.

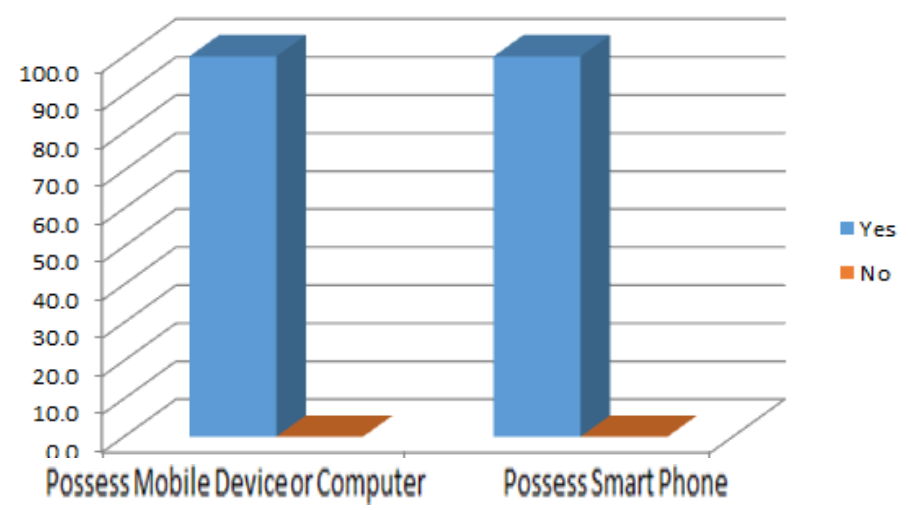

Fig. 1: Possession of Mobile Device or Computers \& Smart or Not

Table 2.0 indicate that, of the $100 \%$ of the students that have access to internet, $91.7 \%$ has access frequently and $8.3 \%$ has access 3 days minimally in a week. In correlation to the access to internet, $83.3 \%$ of the students indicated that their awareness of social media is to a very high extent $12.5 \%$ indicated that, it is to a high extent and the remaining $4.2 \%$ indicated that it is to a moderate extent. This show that students' awareness of social media is to a very high extent and hence when applied to educational benefit, could result in very positive outcome. This is because, the students are not only aware of social media, but they use it and are very conversant with it as indicated in Table 2.0. While $37.5 \%$ of them indicated that they are very conversant with social media, the remaining $29.2 \%$ and $33.3 \%$ indicated that they are conversant and moderately conversant with social media.

TABLE II: INTERNET ACCESS AND SOCIAL MEDIA AWARENESS AND CONVERSANCY

\begin{tabular}{c|c|c|c|c|c|}
\hline \multicolumn{2}{c|}{$\begin{array}{c}\text { Frequency to } \\
\text { Internet Access }\end{array}$} & \multicolumn{2}{c|}{$\begin{array}{c}\text { Extent of Social } \\
\text { Media } \\
\text { Awareness }\end{array}$} & \multicolumn{2}{c|}{$\begin{array}{c}\text { Conversant with } \\
\text { Social Media }\end{array}$} \\
\hline Item & $\%$ & Item & $\%$ & Item & $\%$ \\
\hline $\begin{array}{c}\text { Very } \\
\text { Frequent }\end{array}$ & 91.7 & $\begin{array}{c}\text { Very } \\
\text { High } \\
\text { Extent }\end{array}$ & 83.3 & $\begin{array}{c}\text { Very } \\
\text { Conversant }\end{array}$ & 37.5 \\
\hline $\begin{array}{c}3 \text { to } 4 \\
\text { days per } \\
\text { Week }\end{array}$ & 8.3 & $\begin{array}{c}\text { High } \\
\text { Extent }\end{array}$ & 12.5 & Conversant & 29.2 \\
\hline $\begin{array}{c}1 \text { to } 2 \\
\text { days per } \\
\text { Week }\end{array}$ & 0.0 & $\begin{array}{c}\text { Moderate } \\
\text { Extent }\end{array}$ & 4.2 & $\begin{array}{c}\text { Moderately } \\
\text { Conversant }\end{array}$ & 33.3 \\
\hline Never & 0.0 & $\begin{array}{c}\text { Low } \\
\text { Extent }\end{array}$ & 0.0 & $\begin{array}{c}\text { Not } \\
\text { Conversant }\end{array}$ & 0.0 \\
\hline $\begin{array}{c}\text { Don't } \\
\text { Have } \\
\text { Access }\end{array}$ & 0.0 & $\begin{array}{c}\text { Lowy } \\
\text { Extent }\end{array}$ & 0.0 & $\begin{array}{c}\text { Don't Use } \\
\text { Social Media }\end{array}$ & 0.0 \\
\hline
\end{tabular}

WhatsApp, YouTube and Facebook were the social media that most students use and frequently use. Figure 2.0 demonstrates this as it shows that $29.3 \%$ \& $24.0 \%, 24.0 \%$ \& $20.0 \%$ and $18.3 \%$ and $17.0 \%$ used and frequently used WhatsApp, YouTube and Facebook respectively. This gives an indication on social media platforms that could be leveraged on to enhance students' academic life and possible performance. However, the findings indicate that students do not use the 
social media, line, at all. Further study may need to be carried out to find out why.

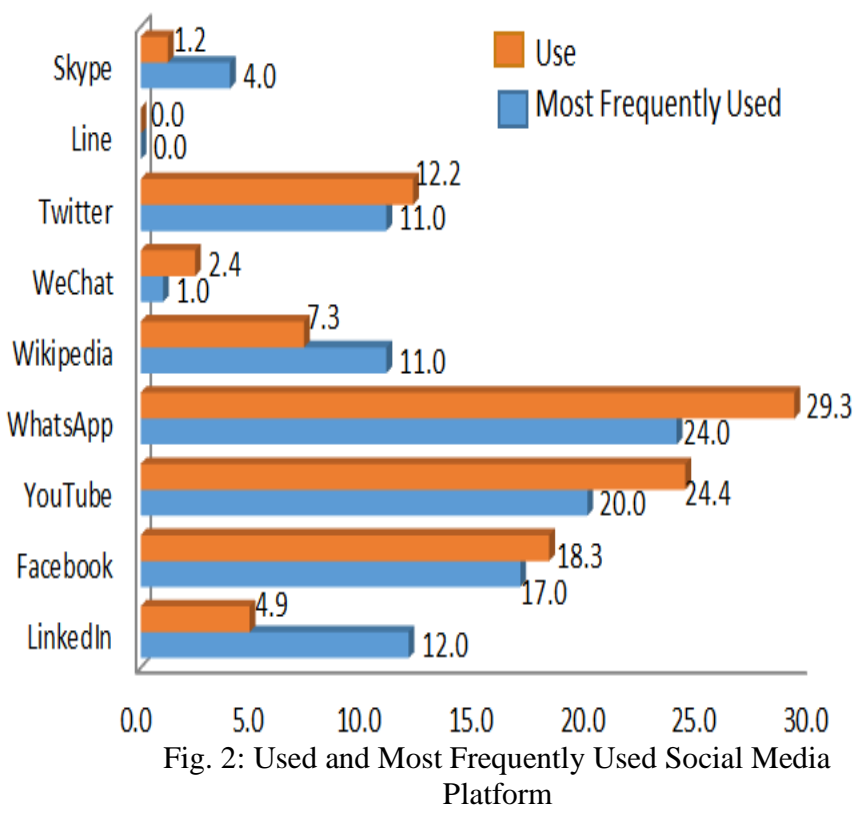

When asked about the number of hours they spend on social media, figure $4.036 \%, 24 \%, 20 \%, 7 \%$ and $4 \%$ indicated that they use it for 3 to 4 hours, 1 to 2 hours, 6 to 7 hours, 8 to 10 hours and above 10 hours respectively per day. Cumulatively, $67 \%$ of the students indicated that they use social media for a minimum of 3 hours per day and in extreme cases, a $4 \%$ use it for more than 10 hours per day. These findings as Figure 3.0 indicate the extent to which students spend time on social media which when channelled to focus on their academic life could results in positive academic performance.

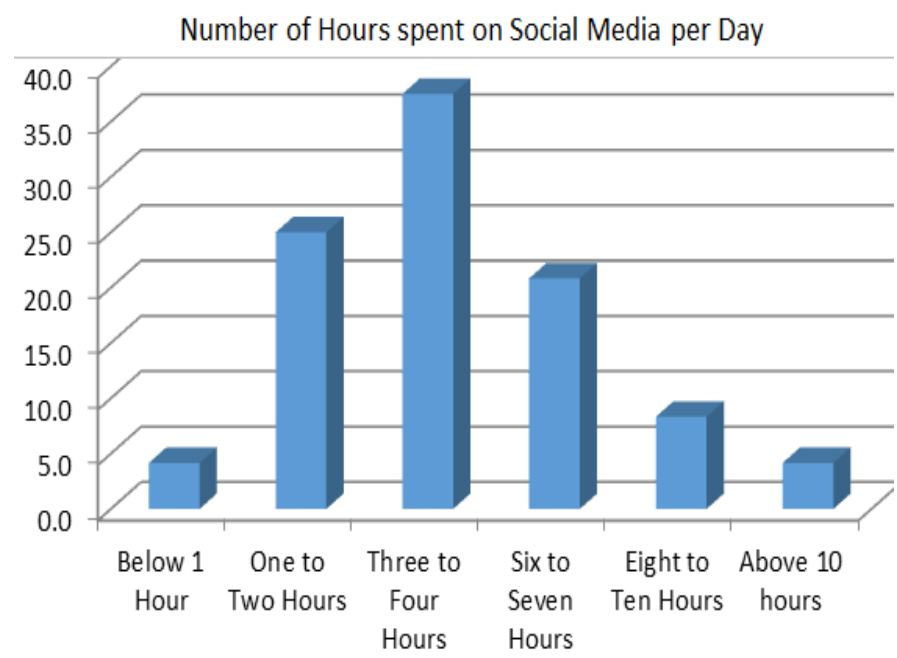

Fig. 3: Number of Hours spent on Social Media per day

On the possibility of using social media for academic purposes and actual usage for academic purposes, $100 \%$ of the students indicated that it's possible to use it and that they are already using for academic purposes. On specific use, they indicated that they use it most often to share resources such as lecture notes, hold online discussions, and discuss class challenges and share class schedules \& timetables among others. This is indicated in Figure 4.0.

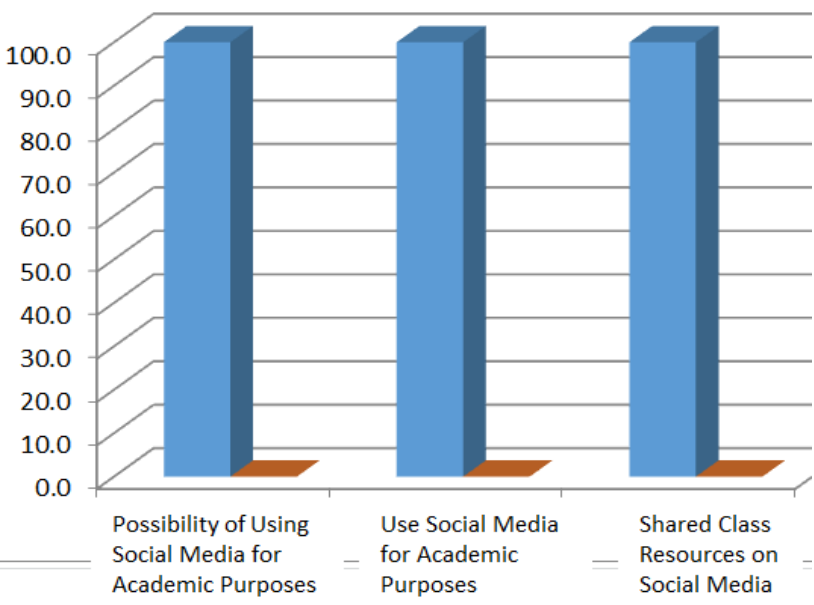

Fig. 4: Social Media for Academic Purpose

On the possibility of using social media supporting students' academic life and the extent to which it is already being used in student academic life, while $62.0 \%$ indicated that it can support their academic life to a very high extent and has already supported them as such, $28.0 \%$ indicated that it can support them to a high extent and has as such and $8.0 \%$ indicated that it can support them moderately and has so far, as such. Figure 5.0 confirms this.

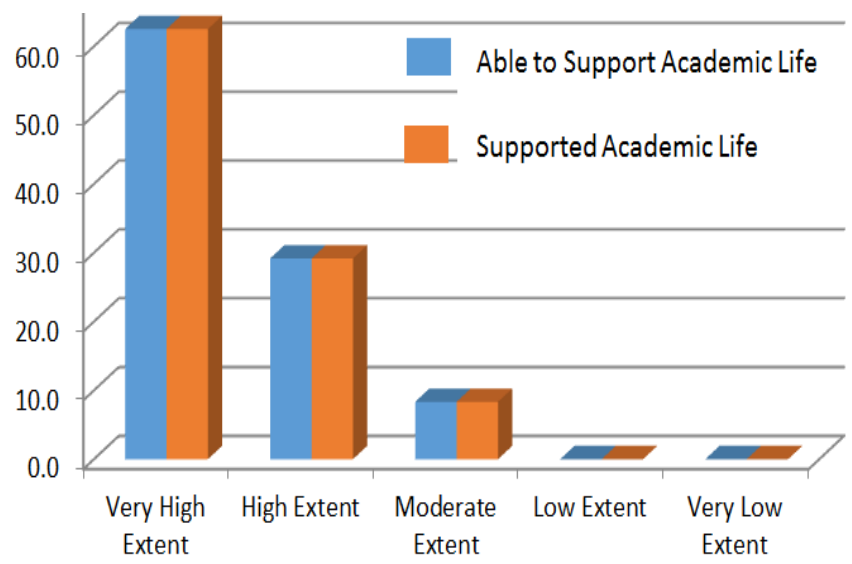

Fig. 5 Extent to which Social Media Supports Academic Life

On the basis that social media supports student academic life as above, $50.0 \%$ and $37.5 \%$ of the students rated social media as very good and good. While no student rated social media as bad, $4.2 \%$ did not respond to this item and $8.3 \%$ responded as neutral. This is demonstrated in Figure 6.0. 


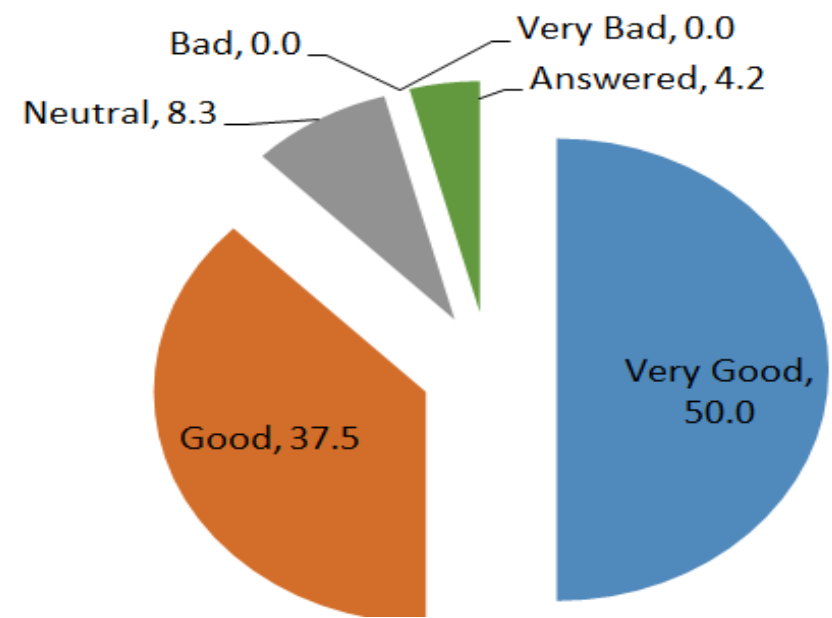

Fig. 6: Social Media Rating based Influence on Academic Life

Challenges in social media support students' academic life in order of highest challenge to the lowest challenge based include distraction, fake news and wrong information, unclear explanation of course content, unnecessary information, missing out important messages on the thread, indecent content, inability to concentrate on one message and language challenge. The two prominent challenges include distraction and fake news \& wrong information $22 \%$ and $17 \%$ (highest frequencies) of the students indicated respectively. This is indicated in Figure 7.0

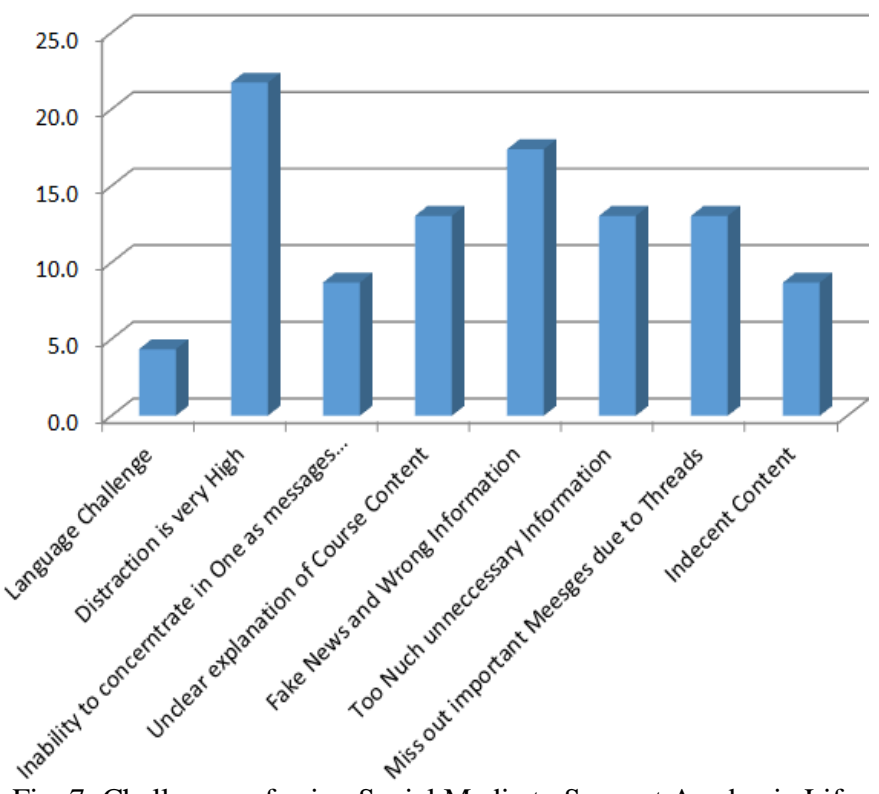

Fig. 7: Challenges of using Social Media to Support Academic Life

\section{DISCUSSION}

The aim of this study was to investigate the perception of the effect of social media on student academic life. This study contributes to the literature on social media effects on student academic life by demonstrating student awareness to social media, access to the Internet, identifying the positive aspects as well as the negative aspects of social media on student academic life.
The findings suggest that the majority of students in learning institutions who took part in this study possess smartphones which they often use to access the Internet and social media platforms. This is in line with other studies which suggest that students use their smartphones for accessing the Internet and social media platforms [34] [35]. However, the findings of this paper may be influenced by the fact that all three institutions where the data was collected are all based in an urban area where Internet access is available.

The most frequently accessed social media platforms are WhatsApp, YouTube, and Facebook. This can be attributed to a lot of factors. First WhatsApp enables sharing of files, creating groups for discussion and sharing information, notices and relevant academic materials. Educational videos relevant to learning can be found on YouTube. In addition, Facebook facilitates interaction and also the creation of groups of similar interests. These could be contributing factors of why students frequently access these specific platforms.

Majority of students' access social media platforms frequently. This is in line with a study in Zambia which suggests that students frequently access social media platforms [36].

While the benefits of social media use impacts students' academic lives positively, there are also negative impacts of social media use in education which includes using wrong information, inability to concentrate on one message and sharing indecent content. It is recommended that social media platforms for educational settings should have restrictions on what can be shared and posted with rules enforced. This can be enacted in WhatsApp groups and Facebook groups where administrators' sets rules and regulations on what can be posted and shared on the platform.

\section{CONCLUSION AND RECOMMENDATION}

Based on the research findings, it can be concluded that students have internet access, are aware of social media and conversant with using it. Among social media that students use and use frequently include WhatsApp, YouTube and Facebook and the most widely used is WhatsApp. Students spend a lot of time on social media, averagely 3 to 4 hours a day. Beyond the possibility of social media being used for academic life, students use social media to support their academic life to a very high extent and on this basis, rated social media as good.

The conclusion above is a wakeup call to stakeholders of education to realise that mobile devices and social media have come to stay and is widely used by students even for academic purposes. Hence stakeholders should put the appropriate policies in place to allow the appropriate use of mobile devices and social media in education instead of restricting its use. For schools without learning management systems, the results of this study indicate that lecturers and students can keep classes on-going after the usual class hours. For disastrous times like the Covid-19 outbreak or natural disasters, social media can be used by lecturers and students to keep teaching and learning going till normality is restored. This study focused on three universities and hence difficult to generalize the findings for all levels of education in Namibia; hence further studies should be conducted to collect data from students at different levels of 
education and after the results be compared with this for further conclusion.

\section{REFERENCE}

[1] Allcott H., Braghieri L., Eichmeyer S., and Gentzkow M. (2019). The Welfare Effects of Social Media. Retrieved from: https://web.stanford.edu/ gentzkow/research/facebook.pdf https://doi.org/10.3386/w25514

[2] Ortiz-Ospina E. (2019). The Rise of Social Media. Our World in Data. Retrieved from: https://ourworldindata.org/rise-of-social-media

[3] Ramírez-Correa P., Grandón E. E., Ramírez-Santana M. and Órdenes B. L. (2019). Explaining the Use of Social Network Sites as Seen by Older Adults: The Enjoyment Component of a Hedonic Information System. International Journal of Environmental Research and Public Health, 16, 1673 . https://doi.org/10.3390/ijerph16101673

[4] Meng J., Martinez L., Holmstrom A., Chung M. and Cox J. (2017). Research on Social Networking Sites and Social Support from 2004 to 2015: A Narrative Review and Directions for Future Research. Cyberpsychol. Behav. Soc. Netw, 20. https://doi.org/10.1089/cyber.2016.0325

[5] Waxer N., Ninan D., Ma A. and Dominguez N. (2013). How Cloud Computing and Social Media Are Changing the Face of Health Care. Physician Exec, 39.

[6] Kemp S. (2019). Digital Trends 2019: Every Single Stat you need to know about the Internet. The next Web. Retrieved from: https://thenextweb.com/contributors/2019/01/30/digital-trends-2019-eve ry-single-stat-you-need-to-know-about-the-internet/

[7] Iyawa, G. E, Herselman, A. and Botha, A. 2016. Digital Health Innovation Ecosystems: From Systematic Literature Review to Conceptual Framework. Procedia Computer Science, 100, pp. 244-252. https://doi.org/10.1016/j.procs.2016.09.149

[8] LCIBS (2019). The Role of Social Media in Education. London College of International Business Studies. Retrieved from: https://www.[16].co.uk/the-role-of-social-media-in-education/

[9] Azizi M. S. and Soroush A. and Khatony A. (2019). The Relationship between Social Networking Addiction and Academic Performance in Iranian Students of Medical Sciences: a Cross-sectional study. BMC Psychology, 7, 28. https://doi.org/10.1186/s40359-019-0305-0

[10] Anderson T. (2019). Challenges and Opportunities for use of Social Media in Higher Education. Journal of Learning for Development, 6(1), 6-19.

[11] Mushtaq J. A. and Benraghda A. (2018). The Effects of Social Media on the Undergraduate Students' Academic Performances. Library Philosophy and Practice (e-journal). 1779.

[12] Mowafy G. (2018). The Effects of Social Media on the Academic Performance of Nile University Students. Department of International \& Comparative Education: Nile University, Nigeria.

[13] Khalid H. (2017). The Effects of Social Networks on Pakistani Students. J Inform Tech Softw Eng, 7, 203. https://doi.org/10.4172/2165-7866.1000203

[14] Judilla R. A. and Gemora B. R. (2016). Influence of Social Networking on the Study Habits and Performance of Students in a State University. Vietnam Academic Research Conference on Global Business, Economics, Finance \& Social Sciences (AP16Vietnam Conference), Hanoi-Vietnam, August, 2016. Retrieved from: www.globalbizresearch.org

[15] Boateng O. R. and Amankwaa A. (2016). The Impact of Social Media on Student Academic Life in Higher Education. Global Journal of Human-Social Science: G Linguistics \& Education, 16(4).

[16] Ujakpa M. M., Heukelman D., Lazarus V. K., Neiss P. \& Rukanda G. D. (2018). Using WhatsApp to Support Communication in Teaching and Learning. IEEE Xplore, Retrieved from: https://ieeexplore.ieee.org/document/8417294/

[17] Faizi R., Afia E. A. and Chiheb R. (2013). Exploring the Potential Benefits of Using Social Media in Education. Ijep, 3(4). https://doi.org/10.3991/ijep.v3i4.2836

[18] Deka P. P. (2015). A Study on Impact of Social Media on Educational Efforts in Guwahati City, Assam. International Journal of Advanced Research in Education Technology 2(3).
[19] Keenan I. D., Slater, J. D., \& Matthan, J. (2018). Social media: Insights for Medical Education from Instructor Perceptions and Usage. MedEdPublish, 7 https://doi.org/10.15694/mep.2018.0000027.1

[20] Manca S., \& Ranieri, M. (2016b). "Yes for sharing, no for teaching!": Social Media in academic practices. The Internet and Higher Education, 29. https://doi.org/10.1016/j.iheduc.2015.12.004

[21] Beland, Louis-Philippe \& Murphy, Richard, 2015. "Ill Communication: Technology, Distraction \& Student Performance," LSE Research Online Documents on Economics 62574, London School of Economics and Political Science, LSE Library.

[22] Kessel D., Hardardottir L. H. and Tyrefors B. (2019). The Impact of Banning Mobile Phones in Swedish Secondary Schools. Research Institute of Industrial Economics. Retrieved from: https://pdfs.semanticscholar.org/a372/13262609832617bfd1ec786f23db e32db712.pdf https://doi.org/10.2139/ssrn.3617386

[23] Bhattacharya S., Bashar M. A., Srivastava, A., \& Singh, A. (2019). Nomophobia: No Mobile Phone Phobia. Journal of Family Medicine and Primary Care, 8(4), 1297-1300. https://doi.org/10.4103/jfmpc.jfmpc_71_19

[24] LinkedIn (2019). About [17]: Mission. Corporation. Retrieved from: https://about.[17].com/?trk=homepage-basic_directory

[25] Boyd D. M., \& Ellison, N. B. (2008). Social network sites: definition, history, and scholarship. Journal of ComputerMediated Communication, 13. https://doi.org/10.1111/j.1083-6101.2007.00393.x

[26] Ezumah A. B. (2013). College Students' Use of Social Media: Site Preferences, Uses and Gratifications Theory Revisited. International Journal of Business and Social Science, 4(5).

[27] Nicholas C. (2010). "At Last: The full story of how Facebook was founded. Business Insider (online, March 5).

[28] Wauters R. (2010, July 21). Zuckerberg makes it official: Facebook hits 500 million members. Retrieved from: http:techcrunch.com/2010/07/21/facebook-500-million/ https://doi.org/10.12968/pnur.2010.21.10.78704

[29] Sauerbier, R. A. (2010). Social networking. In A. E. Grant and J. H. Meadows (Eds.). Communications technology update and fundamentals. Burlington, MA: Focal Press. https://doi.org/10.1016/B978-0-240-81475-9.50020-7

[30] Blumler, J. G. 1979. The role of theory in uses and gratifications studies. Communication Research, 6. https://doi.org/10.1177/009365027900600102

[31] Alsridi H. (2018). Uses and Gratifications of Online News among Young Adults in Bahrain. 4(1). https://doi.org/10.30958/ajmmc.4.1.4

[32] Shava H. \& Chinyamurindi W.T. (2018). Determinants of Social Media Usage among a Sample of Rural South African Youth. South African Journal of Information Management, 20(1). https://doi.org/10.4102/sajim.v20i1.827

[33] Ujakpa M. M. and Heukelman D., (2018). Extended Technological Acceptance Model for Evaluating E-learning: The African Context (ETAM-4EEA). 10th Cape Town International Conference on Education, Business, Humanities and Social Sciences Studies, Cape Town, South Africa. Retrieved from: https://www.eares.org/siteadmin/upload/3350EAP1118444.pdf https://www.earet.org/proceedingspdf.php?id=58

[34] Apuke, O.D. and Iyendo, T.O., 2018. University students' usage of the internet resources for research and learning: forms of access and perceptions of utility. Heliyon, 4(12), p.e01052. https://doi.org/10.1016/j.heliyon.2018.e01052

[35] Atas, A.H. and Çelik, B., 2019. Smartphone Use of University Students: Patterns, Purposes, and Situations. Malaysian Online Journal of Educational Technology, 7(2), pp.59-70. https://doi.org/10.17220/mojet.2019.02.004

[36] Akakandelwa, A. and Walubita, G., 2018. Students' Social Media Use and its Perceived Impact on their Social Life: A Case Study of the University of Zambia. 